Insignia Journal of International Relations

Vol. 6, No.1, April 2019, 1-12

P-ISSN: 2089-1962; E-ISSN: 2597-9868

\title{
NGO dalam Diplomasi Ekonomi: Implementasi Program Sustainable Development Goals (SDG's) Poin Pengentasan Ketimpangan Sosial di Indonesia
}

\author{
Achmad Ismail \\ Departemen Ilmu Hubungan Internasional, Universitas Indonesia \\ Email: ismailachmad@rocketmail.com
}

\begin{abstract}
Abstrak
Perubahan konstelasi global memberikan dampak nyata dari segi aktor diplomasi ekonomi. Jikalau dahulu hanya negara dan MNC yang saling berinteraksi, kini dunia internasional memasukan NGO dan IGO kedalam interaksi diplomasi ekonomi saat ini dengan perannya masing-masing. INFID sebagai NGO berperan penting terhadap aktor diplomasi ekonomi lainnya. Lebih lanjut, dalam diplomasi ekonomi transnasional memiliki spesialisasi dengan memasukan isu transnasional, aktor NGO dan IGO di dalamnya. Artikel ini lebih spesifik menelaah implementasi SDGs di Indonesia -isu pengentasan ketimpangan sosial sebagai isu transnasional menunjukkan tren meningkat di dunia, khususnya di Indonesia. Artikel ini menggunakan metode penelitian kualitatif dengan pendekatan studi kasus maupun studi pustaka. Di lain sisi, artikel ini pula berargumen bahwa INFID memiliki peran penting dalam diplomasi ekonomi transnasional Indonesia dengan cara memberikan peran aktif dengan berbagai cara dalam proses pengambilan kebijakan pemerintah Indonesia maupun pada pertemuan PBB terkait implementasi SDGs poin pengentasan ketimpangan sosial. Pada kesimpulannya, isu pengentasan ketimpangan sosial menjadi isu transnasional yang semakin penting. Merespon isu tersebut, INFID sebagai NGO memiliki peran penting terhadap pengambilan kebijakan pemerintah Indonesia sebagai bagian diplomasi ekonomi transnasionalnya.
\end{abstract}

Kata kunci: NGO, pengurangan ketimpangan sosial, SDGs, diplomasi ekonomi transnasional

\begin{abstract}
Changes in the global constellation have a real impact in terms of economic diplomacy actors. If in the past only the state and MNC interacted with each other, now the international world has included NGOs and IGOs into the interaction of current economic diplomacy with their respective roles. INFID as an NGO plays an important role in other economic diplomacy actors. Furthermore, in transnational economic diplomacy has a specialization by including transnational issues, NGO and IGO actors in it. This article is more specific examine the implementation of SDGs in Indonesia - the issue of alleviating social inequality as a transnational issue shows an increasing trend in the world, especially in Indonesia. This article uses qualitative research methods with case study approach and literature studies. On the other hand, this article also argued that INFID has an important role in the Indonesia's transnational economic diplomacy by playing an active role in various ways in the Indonesian government's policy-making process as well as at UN meetings related to the implementation of the SDGs to reduce social inequality. In conclusion, the issue of alleviating social inequality has become an increasingly important transnational issue. Responding to the issue, INFID as an NGO has important role in the Indonesian government's policy making as part of its transnational economic diplomacy.
\end{abstract}

Keywords: NGOs, social inequality alleviation, SDGs, transnational economic diplomacy 


\section{PENDAHULUAN}

Bulan September 2000 menjadi titik awal lahirnya agenda pembangunan global, atau yang sering dikenal sebagai Millennium Development Goals (MDGs). MDGs tersebut diikuti deklarasi oleh 189 negara. Sudah 3 tahun berlalu sejak tahun 2015, para pemimpin negara di dunia mentransformasikan agenda pembangunan global MDGs ke agenda pembangunan global berkelanjutan atau Sustainable Development Goals (SDGs).

Tentunya SDGs ini memiliki tujuan pembangunan global yang lebih komprehensif dari pendahulunya MDGs dengan 17 poin tujuan pembangunan. Dalam laman resminya, 17 poin SDGs diantaranya, "no poverty, zero hunger, good health and well-being, quality education, gender equality, clean water and sanitation, affordable and clean energy, decent work and economic growth, industry innovations and infrastructure, reduced inequalities, sustainable cities and communities, responsible consumption and production, climate action, life below water, life on land, peace justice and strong institution \& partnership for the goals" (un.org, n.d.). Dengan lahirnya 17 poin ini, negara-negara yang menandatangani kesepakatan SDGs termasuk Indonesia- ini harus melakukan beberapa tindakan untuk mencapai target yang telah ditentukan bersama.

Tujuan ini semakin komprehensif karena berdasarkan prinsip-prinsip HAM, inklusivitas, dan anti-diskriminasi. Agenda SDGs ini pula tidak semata-mata berfokus pada upaya pemenuhan kebutuhan pembangunan masa sekarang, tetapi juga memikirkan pemenuhan kebutuhan pembangunan masa datang. Selain itu, SDGs ditujukan untuk memastikan bahwa semua manusia dapat menikmati kehidupan yang sejahtera dan pembangunan saat ini terjadi selaras dengan lingkungan, lalu dirancang untuk mendorong perdamaian agar terwujud masyarakat adil.

Ketimpangan sosial menjadi sorotan dunia internasional, pasalnya hal ini terjadi di berbagai negara. Menjadi permasalahan manakala negara-negara bersepakat untuk mengurangi ketimpangan sebagai salah satu poin dari SDGs, justru angka ketimpangan semakin meningkat. Catatan lembaga Oxfam Internasional saat ini telah terjadi pemusatan kekayaan di dunia, 50 persen sumber daya alam dikuasai oleh kelompok orang kaya yang jumlahnya hanya 1 persen dari sekitar 8,5 miliar jumlah penduduk dunia (Tempo, 2015). Dapat dibayangkan akses dan kepemilikan capital hanya dimiliki oleh seglintir orang yang jumlahnya sangat sedikit dari total penduduk dunia. Data lain yang menyebutkan bahwa soal ketimpangan sosial sedang mengalami peningkatan hampir di seluruh belahan dunia ditemukan oleh World Inequality Report 2016 menemukan bahwa, ketimpangan sosial sebesar 37 \% di Eropa, 41 \% di China, $46 \%$ di Russia, $47 \%$ di US-Canada, $54 \%$ di SubSahara Afrika, $55 \%$ di Brazil dan India dan $61 \%$ di Timur Tengah (Prawitasari, 2018).

Permasalahan ini dapat ditemui di negara berkembang seperti Indonesia. Ketimpangan sosial yang terjadi di Indonesia masih sangat tinggi. Sebagaimana hasil pengukuran terbaru yang dilakukan International NGO Forum on Indonesian Development (INFID), indeks ketimpangan sosial di tahun 2017 berada di angka 5,6 persen yang sebelumnya naik dari tahun 2016 di angka 4,4 persen (Vebriyanto, 2018). Angka tersebut disarikan dalam penelitian INFID dengan metode wawancara secara acak oleh masyarakat untuk menilai ketimpangan sosial saat ini.

Dalam laporan penelitian INFID, menyebutkan bahwa setidaknya ada 5 sampai 6 ranah ketimpangan, dari 10 ranah yang ditanyakan, yang dirasakan saat ini diantaranya, ketimpangan penghasilan, pekerjaan, rumah, harta benda, kesejahteraan keluarga, pendidikan, lingkungan tempat tinggal, terlibat dalam politik, hukum dan 
kesehatan. Kesepuluh ranah ini menjadi perhatian penting dalam laporan penelitian INFID. Besaran ketimpangan menurut persepsi warga dalam laporannya, penghasilan 71,1 persen, pekerjaan 62,6 persen, rumah atau tempat tinggal 61,2 persen, harta benda 59,4 persen, kesejahteraan keluarga 56,6 persen, pendidikan 54 persen, lingkungan tempat tinggal 52 persen, terlibat politik 48 persen, hukum 45 persen, dan kesehatan 42,3 persen (jsi.web.id, 2018). Bahkan Indonesia saat ini menempati urutan ke-4 negara paling timpang di dunia dengan angka $1 \%$ orang terkaya menguasai 49,3\% kekayaan nasional dan $10 \%$ orang terkaya menguasai $77 \%$ total kekayaan nasional (Tribun News, 2017). Hal ini tidak bisa dipandang sebelah mata, mengingat bahwa ketimpangan yang serius dan berpotensi besar menyebabkan disintegrasi bangsa (Vebriyanto, 2018).

Angka ketimpangan sosial di Indonesia masih cukup tinggi, padahal upaya pengurangan ketimpangan menjadi salah satu poin dari 17 poin utama pembangunan agenda berkelanjutan (SDGs). Upaya-upaya kian gencar dilaksanakan dari level pemerintah pusat, pemerintah daerah hingga level Non-Governmental Organization (NGO) INFID turut andil dalam penyelesaian masalah ketimpangan sosial di Indonesia. Kehadiran NGO INFID tentunya berdampak baik dalam rangka penguatan diplomasi ekonomi Indonesia. Dimana diplomasi ekonomi merupakan proses formulasi maupun negosiasi kebijakan yang berkaitan dengan kegiatan produksi, pertukaran barang, jasa, tenaga kerja dan investasi di negara lain (Rashid, 2005). Namun ketika diplomasi ekonomi memasukkan aktor nonnegara, semisal NGO, IGO, MNC maka hal tersebut dapat digolongkan kedalam diplomasi ekonomi transnasional, sehingga tidak hanya negara yang berperan di dalamnya. Sebagaimana dikatakan oleh Duncan Green \& Phil Bloomer dalam (Woolcock \& Bayne, 2013); Parreira (N.d) beberapa dekade terakhir, NGO telah menunjukkan peningkatan dalam peranan yang relevan dalam area diplomasi ekonomi dengan saluran "advokasi", memberikan peran penting pada kebijakan publik dan berbagai tindakan lainnya. Berdasarkan uraian tersebut, penulis tertarik untuk menelisik lebih dalam, bagaimana peran INFID terhadap kebijakan diplomasi ekonomi transnasional Indonesia terkait implementasi SDGs poin pengentasan ketimpangan?

\section{Tinjauan Literatur}

Beberapa penelitian terdahulu telah menelaah eksistensi serta peran penting dari NGO dalam diplomasi ekonomi yang mana NGO ini kerapkali beroperasi pada level nasional, regional, transnasional yang berfokus pada isu ekonomi, sosial dan politik (Saner \& Yiu, 2003). Bukti nyata lainnta, ketika NGO Greenpeace berperan penting terhadap deforestasi Amazon sebagai masukan penting kebijakan diplomasi ekonomi Brazil terutama dalam menyikapi isu transnasionalisme (Putri, 2016). Contoh lain pada level internasional, manakala Canadians NGO berperan penting dalam negosiasi pembentukan konvensi internasional The Framework Convention on Tobacco Control (FCTC) (Lencucha et.al., 2011). Artikel ini sependapat dengan beberapa artikel sebelumnya, hanya saja artikel ini mencoba menelaah lebih mendalam peran penting NGO INFID pada dimensi sosial -pengentasan ketimpangan sosial- yang mana tidak haya pada level nasional tetapi pada level internasional sebagai masukan terhadap kebijakan diplomasi ekonomi Indonesia. Artikel ini berargumen bahwa peran NGO INFID sama pentingnya dengan pemerintah Indonesia dalam mengambil suatu kebijakan, terkhusus dalam menerapkan SDGs poin pengentasan ketimpangan sosial di Indonesia sebagai instrumen diplomasi ekonomi Indonesia. Lebih dari itu, NGO INFID sudah mulai melebarkan peran pentingnya ke tingkat lebih tinggi dalam pertemuan PBB. Artikel ini bertujuan untuk 
mengidentifikasi besarnya peran non-state actor (NGO) INFID menjadi sumber penting lainnya dalam pengambilan kebijakan pemerintah Indonesia dalam upaya pengentasan ketimpangan sosial sebagai bagian diplomasi ekonominya.

\section{Kerangka Konseptual}

Untuk mengurai pertanyaan tersebut, penulis menggunakan perspektif liberalisme dan konsep diplomasi ekonomi transnasional. Penulis menganggap bahwa liberalisme serta diplomasi ekonomi transnasional memiliki ciri khas yaitu menempatkan aktor non-negara (NGO, IGO, MNC) dalam memberikan peran penting di dalamnya, sehingga hal itu senada dengan fokus dari artikel ini.

Liberalisme dapat dikatakan sebagai "angin segar" bagi para aktor HI non-negara (non-state actor) dengan asumsinya bahwa dalam HI, non-state actor merupakan aktor yang sama pentingnya sebagai entitas nyata selain state actor (Viotti \& Kauppi, 2012). Pada poin ini menggambarkan bahwa semakin banyak non-state actor dalam dunia internasional semakin menaikkan pula urgensi atas peran penting dari eksistensi mereka saat ini. Tak bisa dipungkiri pula NGO serta IGO berkembang pesat guna mewarnai dunia internasional bersama dengan kepentingan yang mereka bawa.

Dikemukakan oleh Steans \& Pettiford (2009) berpendapat bahwa hal ini berkaitan dengan poin liberalisme yang percaya bahwa kebebasan individu di atas segalanya untuk membawa perubahan. Bahkan John Locke berangkat dari nilai liberalisme menganggap bahwa negara muncul untuk menjamin kebebasan warga negaranya tanpa campur tangan pihak lain. Non-state actor bebas menyampaikan pendapatnya ke negara bahkan dunia internasional, sehingga dengan poin kebebasan dalam perspektif ini dapat memberikan perubahan serta pengaruh terhadap dunia internasional.

Viotti \& Kauppi (2012) menjelaskan bahwa perspektif ini pula berasumsi bahwa agenda internasional tidak hanya aspek keamanan (high politics), namun aspek lainnya semisal ekonomi, lingkungan, kemiskinan dan sebagainya (low politics) pula penting untuk dijadikan sebagai agenda dunia internasional, terkadang agenda nonkeamanan ini lebih menonjol, lebih lanjut dalam melihat agenda non-keamanan ini memiliki keterkaitan serta ketergantungan antara state actor dan non-state actor (NGO, IGO dan sebagainya).

Lebih lanjut, diplomasi merupakan salah satu instrumen penting bagi setiap negara guna memenuhi kepentingan nasionalnya. Sebagaimana argumen dari Jonnson \& Hall (2005) mengatakan bahwa diplomasi merupakan instrumen kecerdasan dan kehati-hatian dalam menerapkan strategi untuk memenuhi kepentingan-kepentingan. Sehingga hal ini menandakan bahwa kepentingan nasional menjadi tujuan pokok dari instrumen diplomasi. Secara historis, diplomasi awalnya hanya bersifat politik semata, namun semakin banyak aktor internasional dan isu yang lebih kompleks ditambah adanya globalisasi menjadi pergeseran atau perluasan mencapai kepentingan ekonomi (isu ekonomi) masuk ke ranah diplomasi, yang dikenal sebagai diplomasi ekonomi.

Piere-Bruno Ruffini

(2016) berpendapat bahwa "Economic diplomacy refers to methods and processes by which states take advantage of cross-border economic acivities to achieve their national interest. It makes connections between the sphere of diplomats, who represent the state on international scene and implement geopolitical decisions". Melihat definisi di atas diplomasi ekonomi menandakan sebagai metode bagi negara-negara mengambil keuntungan melalui aktivitas ekonomi melintasi batas demi kepentingan nasional suatu negara. Dengan kata lain, diplomasi ekonomi sebagai penggabungan makna dari tujuan diplomasi dalam konteks kepentingan nasional ekonomi melalui aktivitas ekonomi.

Kajian diplomasi ekonomi kontemporer mengalami transformasi secara cepat. 
Asal mula diplomasi hanya menempatkan aktor negara (state actor) sebagai aktor penting dalam interaksi dunia internasional. Namun, seiring berjalannya waktu implikasi dari berbagai isu global memberikan legitimasi kuat non-state actor untuk mengambil peran penting di dalamnya, khususnya NGO. Pasca-PD II, perubahan terjadi secara signifikan ini diawali dengan narasi "ekonomi" yang awalnya isu lowpolitics menjadi isu high-politics. Secara definisi, diplomasi ekonomi sendiri belum menemukan definisi secara tetap. Hal ini tidak lain disebabkan oleh perubahan aktivitas yang dialami secara cepat, mulai dari segi aktor, cakupan maupun aktivitasnya.

Dari segi aktor, meskipun negara sebagai "panglima" dalam urusan diplomasi, tetapi ada aktor non-negara yang berperan dalam diplomasi ekonomi antara lain, perusahaan-perusahaan yang ikut dalam interaksi ekonomi, pelaku bisnis, NGO, media, asosiasi lokal, dan lain sebagainya (Rivai, 2017). Dari segi cakupannya, Odell (2000) menjelaskan definisi yang lebih luas dengan memasukkan elemen lain yakni adanya kebijakan terkait pertukaran uang dan informasi termasuk bantuan luar negeri atau official development assistance. Dengan perluasan dari beberapa segi tersebut erat kaitannya dengan kajian diplomasi ekonomi transnasional.

Beberapa scholar banyak meneliti tentang eksistensi NGO dan diplomasi ekonomi. Duncan Green dan Phil Bloomer dalam (Woolcock \& Bayne, 2013) mengatakan bahwa beberapa dekade terakhir, NGO internasional lainnya telah mencurahkan peningkatan sumber daya untuk 'advokasi' - menujukkan perannya terhadap kebijakan publik, dan kegiatan aktor lain seperti perusahaan swasta dan lembaga internasional serta fokus dari advokasi internasional tersebut terutama, meskipun tidak secara eksklusif, adalah kebijakan ekonomi. Hampir tidak pernah ada isu yang berkembang baik internasional maupun nasional selalu berdampak pada ekonomi. Pada titik inilah, NGO memainkan peran pentingnya terhadap pemerintah untuk mengeluarkan kebijakan terhadap isu yang berkaitan secara langsung maupun tidak langsung terhadap ekonomi. Hal ini secara tidak langsung NGO berperan tidak langsung dalam level diplomasi ekonomi melalui keberadaan negara, meskipun NGO pula mampu bermain secara langsung dalam level diplomasi ekonomi kontemporer ini.

Senada dengan pernyataan Parreira (N.d.) bahwa LSM sudah memiliki peran yang relevan dalam area diplomasi ekonomi dan setiap model diplomasi ekonomi yang tidak memasukkan NGO menjadi bagian dari masyarakat sipil, dapat dikatakan gagal. Poin pentingnya adalah diplomasi ekonomi transnasional ini menjadi khas ketika aktor yang bermain tidak hanya negara, namun bisa aktor lain, seperti MNC, NGO, media, pelaku bisnis dengan isu-isu transnasional. Tentunya aktor NGO, MNC ini mengandalkan pembentukan opini publik dunia untuk menggapai kepentingan mereka dan membawanya sebagai suatu isu global atau memberikan peran pentingnya pada suatu negara untuk membawa isu/kepentingan mereka ke dalam konstelasi internasional. Begitupula mereka memiliki peran penting dalam ekonomi dan menyajikan jejaring administrasi besar dan pengambilan keputusan berada di negara asal (Kordos \& Vojtovic, 2016).

\section{Metode Penelitian}

Berdasarkan kerangka konseptual yang tertera dalam artikel ini, maka pengumpulan data berpusat pada informasi terkait berbagai upaya pengentasan ketimpangan di Indonesia yang dilakukan oleh INFID sebagai masukan penting bagi pemerintah Indonesia. Artikel ini menggunakan metode penelitian kualitatif dengan pendekatan studi kasus maupun studi pustaka. Menurut Neumann (2014) menambahkan bahwa penelitian studi kasus secara intensif menyelidiki satu atau sekumpulan kecil kasus, berfokus pada banyak detail dalam setiap kasus dan 
konteksnya. Artikel ini menggunakan beberapa data utama, berdasar pada laporan survei ketimpangan sosial INFID tahun 2017 serta data pendukung dari buku, jurnal ilmiah, dokumen maupun artikel dari media online yang terkait.

\section{PEMBAHASAN}

Artikel ini berupaya memaparkan peran penting dari INFID sebagai NGO terhadap kebijakan diplomasi ekonomi Indonesia dalam rangka implementasi SDGs poin pengentasan ketimpangan sebagai bagian dari aktivitas diplomasi ekonomi transnasional Indonesia.

\section{INFID dalam Pusaran Diplomasi Ekonomi Transnasional Indonesia}

Fenomena ketimpangan sosial dalam skala global sudah berlangsung lama, bahkan hingga kini angka tersebut masih cukup besar. Hal ini ditemui di seluruh negara di dunia, termasuk negara maju dan tidak terkecuali di negara berkembang seperti Indonesia. Data pada sub bab sebelumnya telah menyajikan bahwa ketimpangan sosial meningkat dari angka 4,4\% di tahun 2016 menjadi 5,6\% di tahun 2017. Bila ditelisik lebih mendalam bahwa hal ini memiliki spill over effect nyata ke berbagai bidang, khususnya ekonomi. Terlebih poin ketimpangan sosial ini masuk ke dalam salah satu dari 17 poin agenda pembangunan berkelanjutan (SDGs) yang diinisiasi oleh PBB. Indonesia yang sudah menyetujui SDGs ini, sepatutnya melakukan berbagai macam formula untuk mencapai tujuan tersebut sebagai bagian dari upaya diplomasi ekonomi Indonesia. Lebih lanjut, melihat fenomena ini tidak hanya negara yang berperan aktif, ada banyak aktor yang berusaha mengambil peran penting masingmasing. Sebagai NGO, INFID berusaha mengambil peran tersendiri dalam melihat fenomena ini. Interaksi antar aktor NGO dengan negara, dalam konteks ini INFID dan Indonesia menjadi sangat penting dalam rangka upaya diplomasi ekonomi Indonesia di berbagai levelnya.
International NGO Forum on Indonesia Development (INFID) merupakan organisasi non-pemerintah yang bergerak dalam bidang pembangunan di Indonesia. Sejak berdiri tahun 1985, INFID memainkan peran penting dalam proses demokratisasi Indonesia dan memiliki status sebagai lembaga yang diakui dan diakreditasi PBB dengan UN Special Consultation with the ECOSOC sejak tahun 2004 (infid.org, n.d.). Sebagai NGO, sejak tahun 2013 INFID memiliki fokus pada bidang penurunan ketimpangan, pembangunan berkelanjutan 2030, HAM dan demokrasi (infid.org, n.d). Ketiga ini isu ini menjadi penting mengingat bahwa Indonesia mengalami peningkatan ekonomi namun di lain sisi, masalah ketimpangan mengalami peningkatan, isu pembangunan berkelanjutan 2030 ini merupakan agenda pembangunan internasional yang harus dipenuhi oleh setiap negara, sementara isu HAM dan demokrasi merupakan isu pertama atas berdirinya dari INFID. Beberapa peran penting dilakukan INFID terhadap kebijakan diplomasi ekonomi transnasional Indonesia terkait implementasi SDGs khususnya poin pengentasan ketimpangan sosial.

Pertama, keberadaan INFID menjadi instrumen saluran bagi masyarakat untuk menyampaikan aspirasi yang nantinya dibawa ke dalam agenda nasional maupun internasional. Organisasi INFID kerapkali menerima aspirasi dari masyarakat baik secara langsung maupun dengan mengadakan survey terhadap masyarakat. Salah satu contoh nyatanya, ketika INFID melakukan survey tentang ketimpangan sosial di Indonesia tahun 2016/2017 dengan hasil akhir, INFID mengeluarkan laporan survei ketimpangan sosial 2017 (infid.org, n.d.). Hal ini senada dengan pendapat Khasan Ashari (2015) yang menyebutkan bahwa salah satu peran NGO adalah memperjuangkan isu-isu internasional tertentu dan menjadi saluran alternatif untuk menyampaikan aspirasi. Hasil laporan yang telah dikeluarkan ini menjadi sangat penting melihat bahwa NGO akan mengenal 
lebih dalam permasalahan ketimpangan secara nyata pada tataran masyarakat langsung sebagai input laporan sehingga menghasilkan output jelas dan terukur sebagai masukan penting terhadap pengambilan kebijakan diplomasi ekonomi Indonesia. Penting pula bahwa hasil laporan ini perlu disikapi dengan cermat dan cepat sebagai pedoman bagi diplomasi ekonomi Indonesia untuk merancang langkah ke depannya.

Kedua, seringkali NGO melakukan kegiatannya demi mencapai kepentingannya berupaya memobilisasi massa. Hal ini senada dengan penjelasan Khasan Ashari (2015) bahwa salah satu peran NGO adalah melakukan mobilisasi massa untuk memperjuangkan kebijakan. Hal ini dilakukan oleh NGO guna memberikan wawasan baru terhadap isu yang menjadi kepentingan mereka terhadap masyarakat luas serta menambah dukungan agar kepentingan mereka menjadi input besar bagi pemerintah. Dalam situs resminya, melainkan INFID memobilisasi massa untuk menghadiri beberapa kegiatan yang bersifat soft seperti diskusi, press release, konferensi press dan radio talkshow, fellowship, kerjasama hingga advokasi (infid.org, n.d.). Jikalau term memobilisasi massa adalah bentuk demo di jalan, hal itu tidak dilakukan oleh INFID. Dengan kata lain, INFID memobilisasi massa lebih ke arah yang lebih diskusi ilmiah, seminar hingga launching laporan penelitian yang mereka lakukan. Sebagai contoh INFID menyelenggarakan radio talkshow sekaligus kampanye publik di radio MNC Trijaya dalam rangka memperingati Hari Perempuan Internasional, dengan tema "Strategi dan Cara Menurunkan Ketimpangan melalui Pencapaian SDGs" (infid.org, n.d.). Contoh lainnya, adalah ketika INFID mengadakan diskusi publik dan konferensi pers terkait peluncuran laporan hasil survey ketimpangan sosial di Indonesia 2017 dengan mengundang seluruh pewarta berita (infid.org, n.d.). Hal ini dirasa lebih efektif dalam proses memobilisasi massa ketika para pewarta berita akan menyebarkan temuan INFID ini ke masyarakat luas tanpa batasan. Hal ini pula secara tidak langsung membawa wawasan baru hingga pada titik tertentu membangun opini publik sebagai cara untuk mencapai kepentingannya.

Ketiga, kerjasama terhadap jejaring NGO yang telah dibangun (negara, OI dan NGO lainnya) sangat penting dalam upaya penyampaian isu yang ingin dibawa ke ranah global. INFID pun membangun jejaring atau kerjasama dengan negara maupun NGO lainnya untuk membawa isu tertentu. Sebagai contoh INFID dan LSM internasional Oxfam merilis laporan terbaru bahwa kendati jumlah penduduk yang hidup di bawah garis kemiskinan menurun dari 40\% menjadi $8 \%$ sejak tahun 2000, manfaat dari pertumbuhan ekonomi tidak tersebar secara merata, koefisien Gini (Gini Ratio) sebagai salah satu indikator yang menggambarkan tingkat ketimpangan di Indonesia maka semakin besar koefisien Gini, maka semakin lebar kesenjangan antara si kaya dan si miskin (Anugerah, 2017). Tidak hanya membangun jejaring dengan LSM internasional, INFID pula membangun jejaring dengan LSM nasional, semisal WALHI, ICW dan sebagainya. Hal ini menjadi bukti bahwa jejaring yang dibangun menjadi penting untuk mempersiapkan subtansi dari isu-isu yang hendak dijadikan global. Hal ini senada dengan penjelasan Khasan Ashari (2015) yang mana Ia menerangkan bahwa NGO bersama-sama negara, NGO lainnya dan organisasi internasional mempersiapkan subtansi pembahasan isu-isu tertentu. Hal ini tak kalah penting, melihat bahwa kordinasi antara INFID dengan Oxfam dan NGO lainnya guna merumuskan isu pengentasan ketimpangan sosial harus segera ditangani sebagai masukan penting bagi pemerintah Indonesia. Pasalnya hasil dari kordinasi/penelitian NGO merupakan pantauan langsung ke masyarakat (akar rumput) sehingga pemerintah Indonesia dapat mengambil kebijakan diplomasi ekonominya dengan tepat. 
Keempat, NGO pula dapat dikatakan sebagai kelompok penekan di tingkat nasional maupun internasional. Sebagaimana pernyataan Lewis (2003) yang mengemukakan bahwa NGO memainkan peran penting dalam merumuskan kebijakan publik di tingkat lokal, nasional, dan global dan di hampir setiap aspek pembuatan kebijakan. Pada hakikatnya, INFID berperan penting dalam memberikan masukan penting terhadap pemerintah Indonesia untuk segera mengimplementasikan SDGs poin pengentasan ketimpangan sosial sebagai wujud diplomasi ekonomi transnasionalnya. Berbagai metode ditempuh, mulai dari melakukan diskusi, advokasi, saran penyelesaian dan semacamnya. Contoh utamanya manakala INFID seringkali diikutsertakan dalam diskusi dengan pemerintah dan merekomendasikan pemerintah untuk membuat komite kerja bersama SDGs untuk menentukan langkahlangkah yang harus diambil sebagai komitmen SDGs (The Jakarta Post, 2015). Hal ini disambut baik oleh pemerintah agar memberi ruang bagi publik untuk lebih berpartisipasi dalam pembangunan manusia yang berkelanjutan.

Dalam konteks SDGs poin pengentasan ketimpangan sosial, INFID pula dalam laporan survei ketimpangan sosial merekomendasikan kepada pemerintah untuk penyelesaiannya, diantaranya pemberian tunjangan untuk meningkatkan distribusi pendapatan, adanya program sosial dalam bentuk tunjangan untuk meningkatkan keahlian, memberi "paket penyelamatan" bagi orang dewasa yang tidak memiliki gaji pekerjaan layak, memberi bimbingan terhadap jumlah perempuan pada pekerjaan laki-laki, dana pemerintah untuk opsi penitipan anak berkualitas tinggi dan beberapa rekomendasi lainnya (infid.org, n.d.).

Peran penting INFID tidak hanya dirasakan pada tingkat nasional, di tingkat internasional INFID juga terlibat dalam jaringan-jaringan internasional untuk SDGs yang bernama "BEYOND 2015" pula INFID juga aktif di pertemuan-pertemuan internasional terkait SDGs. Semisal sidang PBB di New York September 2013 dan pertemuan open working group on sustainable group di New York Februari 2014 (infid.org, n.d.). Hal ini menandakan bahwa INFID sebagai NGO memainkan peranan pentingnya sebagai kelompok penekan (baik tingkat nasional maupun internasional) dengan membawa isu tertentu untuk mengambil peran dalam pembuatan kebijakan. Peran yang dimainkan ini sangat penting, senada dengan pendapat Clark et.al (1998) yang berpendapat bahwa banyak NGO berperan untuk mempengaruhi pemerintah atau aktor lain secara politis, yang biasanya adalah kelompok advokasi dan lobi dengan tujuan utamanya adalah mengubah kebijakan pemerintah.

Selain itu, INFID pula melakukan advokasi-advokasi dalam hal pengimplementasian SDGs khususnya untuk pengentasan ketimpangan sosial. Di tahun 2018, ada 3 daerah yang pernah mendapatkan advokasi yaitu, Aceh, Jember dan Yogyakarta dengan membentuk Focus Group Discussion (FGD) guna membuat Rencana Aksi Daerah (RAD) di tiap wilayah (infid.org, n.d.). Kegiatan ini senada dengan prinsip dari peran NGO dalam diplomasi ekonomi, dimana Betsill dan Corell (2001) melihat bahwa NGO dapat berdiri di beberapa tujuan, diantaranya meningkatkan kesadaran publik terhadap isu-isu transnasional di sekitar, melobi para pembuat keputusan, mampu memberikan masukan-masukan penting kebijakan domestik maupun luar negeri serta mampu berpartisipasi di dalam dan beberapa tujuan lain.

Bila dianalisis lebih mendalam, walau INFID bukan menjadi aktor utama (hanya sebagai second track) dalam diplomasi ekonomi, tetapi INFID dapat memberikan peran penting yang diterima oleh aktor negara maupun non-negara di ranah diplomasi ekonomi. INFID berperan 
memberikan masukan penting kepada aktor diplomasi ekonomi lainnya dengan menggunakan isu-isu transnasional terkait pembangunan yang menjadi perhatian mereka. Dalam kasus ini INFID menggunakan isu SDGs poin pengentasan ketimpangan sosial sebagai isu untuk menunjukkan peran pentingnya terhadap aktor diplomasi ekonomi lainnya. Tentunya INFID berperan penting terhadap negara dalam hal diskusi, konferensi pers hingga mengeluarkan laporan penelitian agar menjadi pertimbangan bagi Indonesia dalam hal mengeluarkan kebijakan diplomasi ekonominya. Laporan penelitian survei terkait ketimpangan sosial 2017 kemarin menjadi salah satu bukti nyata eksistensi dari INFID sebagai NGO yang bermain dalam diplomasi ekonomi.

Tidak berhenti sampai disitu, INFID pula sudah mulai memperluas jejaring dengan NGO, organisasi internasionalsemisal Oxfam-untuk mendukung isu tertentu di kancah internasional. Kenyataannya, pada tahun 2013, INFID diikutsertakan oleh pemerintah Indonesia dalam sidang PBB terkait SDGs dan berperan aktif dalam working on group on sustainable development. Sehingga dapat diartikan bahwa, INFID tidak hanya memberikan masukan-masukan terhadap pemerintah Indonesia dalam hal implementasi SDGs poin pengentasan ketimpangan sosial dengan berbagai saluran alternatif, namun INFID juga bergerak secara langsung ke dalam interaksi internasional. Hal ini jelas terbukti bahwa diplomasi ekonomi transnasional dapat dijadikan sebagai instrumen penting dalam melihat fenomena ini, dimana interaksi antar aktor terlihat. INFID jelas berinteraksi dengan NGO lain, pemerintah Indonesia bahkan dalam konstelasi internasional dalam hal pengentasan ketimpangan sosial.

Lebih lanjut, meskipun isu pengentasan ketimpangan sosial tidak berdampak langsung dalam hal perdagangan atau aktivitas ekonomi, namun hal ini menjadi penting karena isu ini merupakan bagian dari spill over effect dari aktivitas diplomasi ekonomi. Sehingga hal ini penting sebagai sebuah citra baik Indonesia di mata dunia akan berdampak baik pada investasi dan aktivitas ekonomi lainnya yang masuk ke Indonesia. Hal lain yang hendak digarisbawahi adalah isu pengentasan ketimpangan sosial ini sudah menjadi isu transnasional dan dimasukkan kedalam program SDGs yang tidak kenal batas negara atau sekat-sekat aktor internasional. Aktor-aktor di atas hingga level masyarakat umum sudah sepatutnya turut bertanggung jawab dalam penyelesaian permasalahan ini dengan perannya masing-masing terlebih isu ketimpangan dunia internasional menujukkan tren meningkat. Tidaklah mengherankan bahwa negara, perusahaan dan NGO dalam basis individu dan acapkali bersama-sama aktif dalam usaha diplomatik. Sehingga beberapa tahun terakhir NGO telah meningkatkan keterlibatan mereka dalam sistem perundingan perdagangan dan dalam bantuan pembangunan, dua sektor penting tidak diabaikan. Bahkan pada saat yang sama, beberapa perusahaan mendukung atau menciptakan NGO baru untuk mengembangkan kegiatan sosial mereka. Singkatnya, peningkatan jumlah aktor ini hanya dimungkinkan karena perkembangan teknologi saat ini yang memungkinkan semua aktor ini menjadi bagian dari beberapa jaringan dan komunitas internasional.

Meskipun belum memperlihatkan hasil maksimal, namun pemerintah menerima rekomendasi hasil laporan survei ketimpangan sosial INFID dan meresponnya. Salah satunya ialah kementerian tenaga kerja berupaya memperkuat akses dan mutu pelatihan kerja agar $60 \%$ angkatan kerja di Indonesia yang merupakan lulusan SD-SMP bisa mendapatkan pelatihan dimana program pemagangan terstruktur ini melibatkan sekitar 2648 perusahaan; satu perusahaan diminta untuk menerima pegawai magang 100 orang per tahun (Anugerah, 2017). Berdasar hasil 
rekomendasi tersebut, secara tidak langsung membawa peran penting dalam pembuatan kebijakan pemerintah Indonesia seperti data di atas. Hasil rekomendasi tersebut menjadi bukti bahwa keberadaan NGO saat ini, khususnya INFID berperan penting dalam memberikan masukan-masukan terhadap pemerintah Indonesia sebagai kelompok penekan dalam upaya diplomasi ekonomi transnasional Indonesia.

\section{KESIMPULAN}

Dari subbahasan yang sudah dipaparkan di atas, penulis ber kesimpulan bahwa isu ketimpangan sosial dunia semakin meningkat. termasuk di Indonesia. Hal ini berbanding terbalik manakala negara-negara di dunia, khususnya Indonesia, bersepakat untuk mengurangi isu ketimpangan yang tertuang dalam kesepakatan SDGs. Tentunya, hal ini semakin menarik ketika isu transnasional ini ditelaah kedalam diplomasi ekonomi Indonesia. Beragam aktor di dalamnya memiliki peran masing-masing, terkhusus NGO.

Fenomena NGO dan diplomasi ekonomi transnasional merupakan transformasi baru dalam era globalisasi kini.

\section{DAFTAR PUSTAKA}

\section{Buku dan Artikel}

Ashari, K. (2015). Kamus Hubungan Internasional. Bandung: Nuansa Cendekia.

Clark, A. M.. et al. (1998). The Sovereign Limits of Global Civil Society: A Comparison of NGO Participation in UN World Conferences on the Environment, Human Rights, and Women. World Politics, 51(1).

Jonnson, C. \& Hall, Martin. (2005). Essence of Diplomacy. London: Palgrave Macmillan

Kordos, M. dan Vojtovic, S. (2016). Transnational Corporation in the Global World Economic Environment.
INFID sebagai NGO, pula memainkan peran penting dalam diplomasi ekonomi Indonesia khususnya isu transnasional yaitu implementasi SDGs poin pengentasan ketimpangan sosial. Hadirnya INFID sendiri memainkan peran penting, baik sebagai kelompok penekan terhadap pemerintah Indonesia untuk memberikan peranannya dalam proses pembuatan kebijakan dalam level nasional. Tidak sebatas disitu, maupun terkadang INFID pula menjadi aktor berperan langsung dalam memberikan peranan penting terhadap proses pembuatan kebijakan di level internasional (PBB).

Peningkatan upaya dari INFID sebagai masukan penting terhadap implementasi SDGs poin pengentasan ketimpangan sosial harus terus ditingkatkan. Eksistensi INFID ini berdampak penting terhadap diplomasi ekonomi Indonesia, baik sebagai upaya pengentasan isu ketimpangan, maupun terhadap citra yang dibangun oleh Indonesia dan kesejahteraan masyarakat Indonesia. Lebih lanjut, kajian-kajian di masa mendatang harus terus menelaah mengenai pentingnya peran dari non-state actor (NGO) sebagai bagian penting dalam diplomasi ekonomi transnasional.

Dalam 3rd International Conference on New Challenge in Management and Organization: Organization and Leadership. Procedia-Social and Behavioral Sciences 230.

Lencucha, R., et al. (2011). The Role of NonGovernmetal Organization in Global Health Diplomacy: Negotiating the Framework Convention on Tobacco Control. Health Policy and Planning, 26.

Lewis, D. (2003). Theorizing the Organization and Management of Non-Governmental Organizations. Towards a Composite Approach. Public Management Review, 5(3). 
Neumann, L. (2014). Social Research Methods: Qualitative and Quantitative Approaches ed. 7. Edinburgh: Pearson Education Limited.

Odell, J. S. (2000) Negotiating the World Economy. London: Cornell University Press.

Putri, K. Y. M. (2016). Diplomasi Greenpeace dalam Menekan Deforestasi Amazon. Jurnal Hubungan Internasional, 9(1).

Rivai, A, N. A. (2017). Posisi Indonesia di Tengah Fenomena Korporasi Global (Studi Kasus: Relasi Dagang Indonesia-Toyota Pasca Kesepakatan IJEPA). Indonesian Perspective, 2(2).

Ruffini, P.. (2016). International Trade and Foreign Affairs-Some Reflections on Economic Diplomacy. Journal of International Logistic and Trade, 14(1).

Saner, R. \& Yiu, L. (2003). International Economic Diplomacy: Mutations in Post-modern Times, Discussion Paper in Diplomacy. The Hague: Netherland Institute of International Relations Clingendael.

Steans, J. \& Pettiford, L. (2009). International Relations: Perspectives and Themes. Edinburgh: Pearson Education.

Viotti, P. \& Kauppi, M. (2012). International Relations Theory $5^{\text {th }} E d$. New York: Pearson Education.

Woolcock, S. \& Bayne, N. (2013). New Economic Diplomacy: Decision-Making and Negotiations in International Economic Relations. Ashgate: Ashgate Publishing Ltd.

\section{Artikel Daring}

Administrator. (N.d.). "Sustainable Development Knowledge Platform." Diakses dari https://sustainabledevelopment.un.o rg/sdgs. (2018). "Survei INFID 2017:

Ketimpangan Sosial Indonesia Meningkat". Diakses dari http://www.jsithopi.org/2018/02/su rvei-infid-2017-ketimpangan-sosialindonesia-meningkat/.

Anugerah, P. (2017). "Harta Empat Orang di Indonesia Setara Gabungan Kekayaan 100 Juta Orang Miskin". Diakses dari http://www.bbc.com/indonesia/indo nesia-39060857.

INFID. (2017). “Laporan Survei

Ketimpangan Sosial 2017”. Diakses dari http://www.infid.org/laporansurvei-ketimpangan-sosial-infid2017/.

(N.d.). “Tentang INFID”. Diakses dari http://www.infid.org/.

(N.d.). "Fokus Area INFID". Diakses dari http://www.infid.org/fokusarea/.

(N.d.). "Kegiatan INFID”. Diakses dari

http://www.infid.org/category/kegia $\tan /$.

(N.d.). "Radio Talkshow: Strategi dan Cara Menurunkan Ketimpangan Melalui Pencapaian SDGs". Diakses dari http://www.infid.org/110/. (N.d.). "Konferensi Pers: Launching Survey Ketimpangan Sosial 2017". Diakses dari http://www.infid.org/konferensipers-launching-survey-ketimpangansosial-2017/.

(N.d.). "Agenda Pembangunan

2030". Diakses dari

http://www.infid.org/fokusarea/sdgs/.

(N.d.). "INFID Advokasi Pelaksanaan SDGs 3 di Daerah". Diakses dari http://www.infid.org/infid-advokasipelaksanaan-sdgs-di-3-daerah/.

Parreira, P. C. (N.d.). Some Considerations about the State of the Art of the "New Economic Diplomacy". Diakses dari https://pdfs.semanticscholar.org/04 6a/3a3b3c418ac7740a90e5d49d1c9 5d46d4033.pdf.

Prawitasari, D. (2018). "Kesenjangan Sosial Terjadi Hampir di Semua Negara”. Diakses dari 
http://nationalgeographic.co.id/berit a/2018/01/kesenjangan-sosialterjadi-hampir-di-semua-negara.

Rashid, H. (2005). "Economic Diplomacy in South Asia". Diakses dari https://crawford.anu.edu.au/acde/as arc/pdf/papers/conference/CONF20 05_04.pdf

The Jakarta Post. (2015). "INFID Calls for Immediate Creation of Joint Committee for SDGs Implementation". Diakses dari http://www.thejakartapost.com/new s/2015/12/23/infid-callsimmediate-creation-joint-committeesdgs-implementation.html.

Tempo. (2015). "Masyarakat Internasional Soroti Ketimpangan Sosial." Diakses dari

https://nasional.tempo.co/read/703 970/masyarakat-internasionalsoroti-ketimpangan-sosial.
Tribun News. (2017). “Indonesia Urutan Ke-4 di Dunia Masalah Ketimpangan Sosial Ekonomi Antara Kota Dan Desa". Diakses dari http://www.tribunnews.com/nasion al/2017/12/20/indonesia-urutan-ke4-di-dunia-masalah-ketimpangansosial-ekonomi-antara-kota-dandesa.

Vebriyanto, W. (2018). "INFID:

Ketimpangan Sosial Meningkat di 2017". Diakses dari http://politik.rmol.co/read/2018/02 /08/326011/INFID:-KetimpanganSosial-Meningkat-Di-2017-. (2018). "Ketimpangan Ekonomi Bisa Picu Disentegrasi Bangsa”. Diakses dari http://politik.rmol.co/read/2018/03 /06/329352/Ketimpangan-EkonomiBisa-Picu-Disintegrasi-Bangsa-. 